\title{
COMPARISON OF EFFECTS OF THREE ANAESTHETIC TECHNIQUES ON PATIENTS WITH SEVERE PULMONARY OBSTRUCTIVE DISEASE*
}

\author{
Azmy R. Boutros, M.D. and Mary Weisel, M.D. $\nmid$
}

ThE PURPose of this study was to compare the effects of three anaesthetic techniques when used for major abdominal surgery in a group of patients with well defined and measurable degrees of pulmonary disability. The techniques compared were (1) nitrous oxide anaesthesia with d-tubocurarine, (2) lumber epidural block supplemented with nitrous oxide, (3) nitrous oxide and diethyl ether. Arterial blood gases, pulmonary function studies and the clinical course were analyzed to define the postoperative respiratory status.

\section{METHODS}

All patients were men admitted for major abdominal procedures. A singlebreath expirogram using the Vitalor apparatus ${ }^{1,2}$ was taken by a trained technician. The one criterion for inclusion in this study was a maximum expiratory How rate (MEFR) of less than 75 liters per minute which was considered indicative of a severe degree of obstructive pulmonary disease. ${ }^{3,4}$ The test was repeated several times over a period of days to ensure uniformity of results. When MEFR was less than $75 \mathrm{~L} / \mathrm{min}$, arterial blood sampling for $\mathrm{PaO}_{2}, \mathrm{PaCO}_{2}$, and $\mathrm{pH}$, chest $\mathrm{x}$-rays, and ECG were done. If pulmonary infection was present, the operation was delayed and the patient was given appropriate antibiotic therapy following which the MEFR was remeasured. One of the three anaesthetic techniques was selected at random on the day before the operation.

On the morning of the operation, patients in the curare group were premedicated with morphine and scopolamine (average doses $5.5 \mathrm{mg}$ and $0.25 \mathrm{mg}$ respectively) and patients in the epidural and ether groups received pentobarbital (Nembutal ${ }^{\circledR}$ ) and scopolamine (average doses $75.4 \mathrm{mg}$ and $0.32 \mathrm{mg}$ respectively). The brachial or radial arteries were cannulated using a modified Seldinger technique..$^{5}$ Anaesthesia was administered by anaesthesia residents under close supervision by one of the authors.

Anaesthetic techniques: Nitrous oxide - d-tubocurarine anaesthesia ${ }^{6}$ was induced with thiopental and d-tubocurarine and maintained with nitrous oxideoxygen $(7: 3 \mathrm{~L} / \mathrm{min}$ ), and repeated increments of curare. Reversal of curarization was accomplished with atropine and neostigmine and evaluated with a nerve-muscle stimulator.

Epidural block to the level of the fifth thoracic dermatome was established

- From the Department of Anaesthesia, University of Iowa College of Medicine, Iowa City, Iowa 52240. With the technical assistance of Larry Rigler and Thomas Kock.

†Present address: 5300 Vernon Avenue, Ediria, Minnesota 55436. 
by injecting lidocaine 2 per cent with 1:200,000 epinephrine and maintained by means of a catheter placed into the epidural space. General anaesthesia was then induced with nitrous oxide-oxygen $(7: 3 \mathrm{~L} / \mathrm{min})$. The trachea was sprayed with a topical anaesthetic and intubated following intravenous succinylcholine $40 \mathrm{mgm}$. Anaesthesia then was maintained with the same concentration of nitrous oxide-oxygen and with increments of 2 per cent lidocaine injected into the epidural space.

Nitrous oxide-diethyl ether anaesthesia was induced by mask with nitrous oxide-oxygen $(6: 4 \mathrm{~L} / \mathrm{min})$. Ether was slowly added to the inspired gases until the patient was deeply anaesthetized. The trachea was then intubated and anaesthesia was maintained as before.

Ventilation pattern: The lungs were mechanically ventilated in all patients using a combination of a Bird ${ }^{\circledR}$ Ventilator and a Roswell Park Ventimeter ${ }^{\circledR}$ (Air Shields, Inc). ${ }^{7}$ Minute ventilation was adjusted to maintain a $\mathrm{PaCO}_{2}$ of $30-40$ torr. The length of expiration was measured following a single hyperinflation by listening to the trachea with a stethoscope. The rate of ventilation was then adjusted to provide a ratio of inspiration to expiration of 1:2. Expiratory resistance on the Bird Ventilator was set to maintain a slight positive pressure (approximately $5 \mathrm{cms}$ water) during the major part of the expiratory phase.

Arterial blood gases were measured repeatedly in duplicate both during the procedure and again $30,60,120$, and 180 minutes thereafter. The determinations were done every day for three days postoperatively. Measurements were done on the I.L. pH and blood gas analyses - Model 113 with appropriate corrections to oesophageal temperatures. MEFr was measured on the first three postoperative days. Patients were taken from the Recovery Room to the Intensive Care Unit where they remained for at least three days. During that time they were closely observed and constantly prompted to cough and breathe deeply. Patients were followed until discharged from the hospital and all complications were recorded. Statistical evaluation of the results was done using analysis of variance and Student's $t$ test.

\section{Results}

A total of 1019 patients was examined with the Vitalor apparatus between April, 1965 and October, 1968. Sixty-nine patients (6.7 per cent) were found to have an MEFr of less than $75 \mathrm{~L} / \mathrm{min}$. Of these, 28 patients $(2.75$ per cent of total patients examined) underwent major abdominal operations. The distribution of varying values of MEFR in the three groups is shown in Table I. Table II shows numbers, average age, weight, and height as well as average values of other variables measured preoperatively in each group. Intraoperative variables are shown in Table III. In 4 of the 9 ether patients, maintenance of mechanically controlled ventilation was not possible. Spontaneous respirations were manually assisted using a tight reservoir bag, thus maintaining a pressure above atmospheric (approximately $5 \mathrm{cms}$ water) during expiration. This pattern of ventilation resulted in average values for $\mathrm{PaO}_{2}$ and $\mathrm{PaCO}_{2}$ similar to those obtained in the ether cases whose ventilation was controlled mechanically.

Intravenous ephedrine was used during the operation in 3 cases in the curare 
TABLE I

DistribUtion OF MEFR IN VARIOUS GROUPS

\begin{tabular}{lcccc}
\hline $\begin{array}{c}\text { MEFR } \\
\text { L/min }\end{array}$ & Total & Curare & Epidural & Ether \\
\hline $\begin{array}{l}\text { Less than } 20 \\
21-30\end{array}$ & $7^{*}$ & 4 & 2 & 2 \\
$31-40$ & 6 & 3 & 2 & 1 \\
$41-50$ & 2 & 0 & 1 & 1 \\
$51-60$ & 7 & 3 & 1 & 0 \\
$61-70$ & 3 & 2 & 0 & 2 \\
$71-75$ & 2 & 0 & 1 & 0 \\
Total & 1 & 0 & 8 & 9 \\
\hline \\
*One patient was operated upon twice and was included in the \\
epidural and ether groups.
\end{tabular}

TABLE II

Average Values for Measured Preoperative Variables

\begin{tabular}{lllllllll}
\hline \hline Group & $\begin{array}{c}\text { Age } \\
\text { (yrs) }\end{array}$ & $\begin{array}{c}\text { Weight } \\
\text { (lbs) }\end{array}$ & $\begin{array}{c}\text { Height } \\
\text { (inches) }\end{array}$ & $\begin{array}{c}\mathrm{MEFR} \\
(\mathrm{L} / \mathrm{min})\end{array}$ & $\mathrm{FEV}_{1,0}{ }^{*}$ & $\begin{array}{c}\mathrm{PaO}_{2} \\
\text { (torr) }\end{array}$ & $\begin{array}{c}\mathrm{PaCO}_{2} \\
\text { (torr) }\end{array}$ & pH \\
\hline $\begin{array}{c}\text { Curare } \\
(12 \text { cases) }\end{array}$ & 68.6 & 138.6 & 67.4 & 32.7 & 32.9 & 65.5 & 42.7 & 7.455 \\
$\begin{array}{c}\text { Epidural } \\
(8 \text { cases) }\end{array}$ & 66 & 151.6 & 68.5 & 36 & 33.5 & 66.9 & 44 & 7.448 \\
$\begin{array}{c}\text { Ether } \\
(9 \text { cases) }\end{array}$ & 68 & 152.3 & 69.3 & 40.5 & 35 & 61 & 40.2 & 7.459 \\
\hline
\end{tabular}

*Expressed as percent of predicted values.

TABLE III

InTraoperative Data

(average values and range)

\begin{tabular}{|c|c|c|c|c|c|}
\hline Group & $\mathrm{F}_{1} \mathrm{O}_{2}$ & $\begin{array}{l}\mathrm{PaO}_{2} \\
\text { (torr) }\end{array}$ & $\begin{array}{c}\mathrm{PaCO}_{2} \\
\text { (torr) }\end{array}$ & $\begin{array}{c}\text { Duration of } \\
\text { induction } \\
\text { (min) }\end{array}$ & $\begin{array}{l}\text { Duration of } \\
\text { anaesthesia } \\
\text { (min) }\end{array}$ \\
\hline Curare & 0.3 & $\begin{array}{l}106.3 \\
(70-175)\end{array}$ & $\begin{array}{l}34.5 \\
(21-55)\end{array}$ & $\begin{array}{l}28.2 \\
(15-45)\end{array}$ & $\begin{array}{l}152.5 \\
(50-285)\end{array}$ \\
\hline Epidural & 0.3 & $\begin{array}{l}109.5 \\
(85-150)\end{array}$ & $\begin{array}{l}33.6 \\
(25-43)\end{array}$ & $\begin{array}{l}37.5 \\
(25-60)\end{array}$ & $\begin{array}{l}191.8 \\
(45-285)\end{array}$ \\
\hline Ether & 0.4 & $\begin{array}{l}199.5 \\
(62-240)\end{array}$ & $\begin{array}{l}31.5 \\
(21-46.5)\end{array}$ & $\begin{array}{l}35.5 \\
(20-45)\end{array}$ & $\begin{array}{l}146.6 \\
(60-240)\end{array}$ \\
\hline
\end{tabular}

group, in 6 cases in the epidural group and in one case in the ether group. The vasopressor was given whenever systolic blood pressure decreased by more than 40 per cent of the preanaesthetic level and remained low for more than 5 minutes.

Four patients in the curare group, one in the epidural group and five in the ether group showed $\mathrm{PaO}_{2}$ values of less than 55 torr during the first three hours postoperatively, and required administration of oxygen nasally and frequent measurements of arterial blood gases. Mechanically assisted ventilation was started whenever a progressive increase in $\mathrm{PaCO}_{2}$ was noted. It was required in three patients in the curare group. In two of these assisted ventilation was started immediately following operation despite the fact that curarization ap- 
TABLE IV

Average Changes from Preoperative Control Values

\begin{tabular}{|c|c|c|c|c|c|c|c|}
\hline \multirow{3}{*}{$\mathrm{PaO}_{2}$ (torr) } & \multirow[b]{2}{*}{$30 \mathrm{~min}$} & \multirow[b]{2}{*}{$60 \mathrm{~min}$} & \multicolumn{3}{|c|}{ Time following operation } & \multirow[b]{2}{*}{$48 \mathrm{hr}$} & \multirow[b]{2}{*}{$72 \mathrm{hr}$} \\
\hline & & & $120 \mathrm{~min}$ & $180 \mathrm{~min}$ & $24 \mathrm{hr}$ & & \\
\hline & & & & & & & \\
\hline Curare & -7 & -6 & -5.4 & -4.3 & -7.2 & -9.8 & -5.7 \\
\hline Epidural & +1 & -1.6 & -3.9 & -5.5 & -9.1 & -9.9 & -12.1 \\
\hline Ether & -4.3 & -3.6 & -3.2 & -1.7 & -4 & -3.5 & -0.5 \\
\hline \multicolumn{8}{|c|}{$\mathrm{PaCO}_{2}$ (torr) } \\
\hline Curare & -0.5 & -1.7 & -2.8 & -4 & -3.7 & -6.7 & -4.7 \\
\hline Epidural & -0.2 & +0.5 & -0.3 & -0.3 & 0 & -0.4 & +4.6 \\
\hline Ether & +1.3 & +0.7 & -0.5 & 0 & -1.3 & -4.4 & -1.0 \\
\hline \multicolumn{8}{|c|}{ MEFR (per cent change) } \\
\hline Curare & & & & & -38 & -52.5 & -32.4 \\
\hline Epidural & & & & & -34 & -53 & -29 \\
\hline Ether & & & & & -42 & -40.5 & -37 \\
\hline
\end{tabular}

peared to be reversed as indicated by the nerve-muscle stimulator. Assisted ventilation continued until the first postoperative morning. The third patient suffered acute myocardial infarction on the fourth postoperative day and his ventilation was assisted for 24 hours. Two patients in the epidural group required mechanically assisted ventilation, one on the second day postoperatively and the other on the fourth, fifth, and sixth postoperative days. None of the patients in the ether group required assisted ventilation. Four of the five patients who required mechanical ventilation at some time in the postoperative period had preoperative MEFr values of less than $20 \mathrm{~L} / \mathrm{min}$. The remaining one patient had a MEFR of $45 \mathrm{~L} / \mathrm{min}$. In no instance was tracheostomy required.

Twelve patients ( 7 in curare group, 2 in epidural group, and 3 in ether group) required immediate postoperative sedation in the form of morphine sulphate. In 8 of these patients, comparison of $\mathrm{PaO}_{2}$ and $\mathrm{PaCO}_{2}$ values before and 30-90 minutes after intramuscular injection of $5 \mathrm{mg}$ morphine was possible and revealed insignificant average falls in both $\mathrm{PaO}_{2}$ (1.5 torr) and $\mathrm{PaCO}_{2}$ (1.6 torr).

Average changes in arterial blood gases and MEFR from preoperative control values at $30,60,120$, and 180 minutes and at 24,48 , and 72 hours are shown in Table IV. The only statistically significant difference among the groups occurred at 72 hours in $\mathrm{PaO}_{2}(p<0.05)$ and $\mathrm{PaCO}_{2}(p<0.05)$ values.

The average length of stay in the hospital following operation was 12.9, 14.3, and 16.1 days in the curare, epidural, and ether groups respectively. These figures do not differ significantly.

There were two deaths in this study. One patient in the curare group died on the 13th postoperative day following myocardial infarction. The other patient, in the ether group, underwent a second laparotomy on the 3rd postoperative day because of a ruptured viscus. He died a day later of severe peritonitis and toxaemia.

Postoperative temperature rise to $101^{\circ} \mathrm{F}$ or more orally was recorded in two patients in the curare group, two patients in the epidural group, and in none of the patients in the ether group. Three of these four patients also required mechanically assisted ventilation sometime during their postoperative course. 


\section{Discussion}

Over the past two decades, several studies on the effects of anaesthetic agents and techniques in patients suffering from pulmonary disability have been reported. ${ }^{8-13}$ A shortcoming of most of these studies was the lack of definition of the degree of disability. Patients were included in a study on the basis of history or clinical findings without determining the degree of functional involvement of the pulmonary system. The use of MEFR as a measure of the degree of disability has been recommended by several authors ${ }^{3,4,14}$ who considered it to be the most sensitive measurement in obstructive lung disease. They considered MEFR of less than $200 \mathrm{~L} / \mathrm{min}$ to be indicative of functional impairment. In this study, MEFr of $75 \mathrm{~L} / \mathrm{min}$ or less was arbitrarily chosen as indicative of severe pulmonary obstructive disease.

The anaesthetic techniques and agents used in this study represented three common anaesthetic approaches. We chose diethyl ether because it could be used unsupplemented for upper abdominal procedures. Light general anaesthesia was used to supplement epidural analgesia so as to render the patient unconscious during upper abdominal surgery, and to ensure adequate ventilation regardless of the level of epidural block.

Induction of anaesthesia was smooth in all cases except for two in the ether group. There was no difference among groups in average duration of induction. None of the patients in the curare group developed wheezing or "bronchospasm" on receiving large doses of muscle relaxant.

Three patients (one in epidural group and two in the ether group) coughed for a few minutes after the trachea had been intubated. It seemed that deep general anaesthesia or profound muscle paralysis with light general anaesthesia were fairly adequate in preventing patients with obstructive lung disease from reacting to the insertion of a tube in the trachea.

The pattern of ventilation most appropriate for patients with severe obstructive pulmonary disease has not been clearly defined. Airway obstruction in severe emphysema is due to collapse of bronchial walls during expiration. ${ }^{15}$ Maintenance of slight positive pressure during expiration helps to keep these bronchi open, thus reducing air trapping. This is enhanced by allowing enough time for the expiratory phase. Expiratory time in patients in this study ranged between 3-8 seconds. Thus in some patients, ventilation rate was as slow as 4-5/minute.

With the elimination of the anaesthetic technique and agents as important variables in the outcome of anaesthesia and operation in patients with severe obstructive pulmonary disease, it is possible to analyze the results of these cases as a group.

The incidence of mechanically assisted ventilation in the postoperative period seemed to be related to the degree of disability. Four ( 57 per cent) of the seven patients with MEFR less than $20 \mathrm{~L} / \mathrm{min}$ and one (4.7 per cent) of the remaining 21 patients required assisted ventilation.

In a previous study, ${ }^{6}$ male and female patients with no known pulmonary disease and normal average maximum inspiratory force were anaesthetized with 
TABLE V

Preoperative and Postoperative Variables in Patients with No Known Pulmonary Disease versus those of Patients with Severe Pulmonary Disability

\begin{tabular}{|c|c|c|c|}
\hline & $\begin{array}{c}\text { Patients with no known } \\
\text { pulmonary disease }\end{array}$ & $\begin{array}{l}\text { Patients with severe } \\
\text { pulmonary disability }\end{array}$ & Significance \\
\hline Age (years) & 60.5 & 67.6 & $p<0.05$ \\
\hline $\begin{array}{l}\text { Preop. values } \\
\mathrm{PaO}_{2} \text { (torr) } \\
\mathrm{PaCO}_{2} \text { (torr) }\end{array}$ & $\begin{array}{l}76.4 \\
37.2\end{array}$ & $\begin{array}{l}64.5 \\
42.1\end{array}$ & $\begin{array}{l}p<0.001 \\
p<0.005\end{array}$ \\
\hline \multicolumn{4}{|l|}{$\begin{array}{l}\text { Postop. values } \\
\text { (Change from } \\
\text { preop. values) }\end{array}$} \\
\hline $\begin{array}{l}\text { 1st hour } \\
\mathrm{PaO}_{2} \text { (torr) } \\
\mathrm{PaCO}_{2} \text { (torr) }\end{array}$ & $\begin{array}{l}-6.6 \\
+1.8\end{array}$ & $\begin{array}{l}-3.8 \\
-0.8\end{array}$ & $\begin{array}{l}\text { NS } \\
\text { NS }\end{array}$ \\
\hline $\begin{array}{l}\text { 1st day } \\
\mathrm{PaCO}_{2} \text { (torr) }\end{array}$ & $\begin{array}{r}-13.1 \\
-1.2\end{array}$ & $\begin{array}{l}-6.8 \\
-2.1\end{array}$ & $\begin{array}{l}p<0.01 \\
\text { NS }\end{array}$ \\
\hline $\begin{array}{l}\text { 3rd day } \\
\mathrm{PaO}_{2} \text { (torr) } \\
\mathrm{PaCO}_{2} \text { (torr) }\end{array}$ & $\begin{array}{l}-8.4 \\
-0.8\end{array}$ & $\begin{array}{l}-5.7 \\
-1.0\end{array}$ & $\begin{array}{l}\text { NS } \\
\text { NS }\end{array}$ \\
\hline $\begin{array}{l}\text { Postoperative } \\
\text { hospital stay (days) }\end{array}$ & $12.7^{*}$ & 14.2 & NS \\
\hline
\end{tabular}

*Unpublished data.

three different anaesthetic agents during major abdominal operations. Patients remained in a postanaesthetic recovery area for 24 hours, after which they were transferred to their respective wards. Respiratory adequacy was assessed by means of arterial blood gas determinations and inspiratory force measurements at the 1st hour, the 1st day, and 3rd day postoperatively. There were no significant differences between anaesthetic techniques. A comparison between results obtained in male patients in that study and those obtained in the present study is shown in Table V. From this it is evident that the outcome of anaesthesia and operation in patients with severe pulmonary disability in our study did not differ from the outcome in patients with no known pulmonary disease receiving "standard" postoperative care. However, the comparison failed to indicate whether a difference might have existed if both disabled and normal patients received the same postoperative care.

\section{SUMMARY}

Effects of d-tubocurarine, lumbar epidural, or diethyl-ether anaesthesia, each supplemented with nitrous oxide and oxygen were studied during major abdominal surgical procedures in 28 patients with maximum expiratory flow rates (MEFR) of less than $75 \mathrm{~L} / \mathrm{min}$. Ventilatory patterns during operation consisted of prolonged inspiratory and expiratory phases. Airway pressure was maintained at $5 \mathrm{cms}$ of water above atmospheric pressure during the major part of expiration. Blood gases, MEFR, and the clinical course were the variables used to define postoperative respiratory status. There were no real differences between the 
groups. Two patients died and five required mechanically assisted ventilation sometime in the postoperative period. A comparison of results of this study with those of a previous study on patients with no known lung disease showed no difference in postoperative changes in blood gases and length of hospital stay.

\section{RÉSUMÉ}

Au cours d'opérations abdominales majeures chez 28 malades, nous avons étudié, à l'aide des vitesses maximales d'expiration (MEFr) de moins de 75 litres/minute, les effects de la d-tubocurarine, de l'épidurale lombaire ou de l'anesthésie à l'éther éthylique, alors que chacune de ces anesthésies était complétée par du protoxyde d'azote et de l'oxygène. Au cours de l'opération, les tracés ventilatoires ont montré des phases inspiratoires et expiratoires prolongées. Au cours de la plus grande durée de l'expiration, nous avons maintenu dans les voies respiratoires une pression de $5 \mathrm{~cm}$ d'eau supérieure à la pression atmosphérique. Les gaz du sang artériel, la MEFR et l'évolution clinique ont constitué les critères pour définir l'état respiratoire post-opératoire. Nous n'avons pas observé de différences entre les divers groupes. Nous avons perdu deux malades et nous avons dû fournir une ventilation mécanique occasionnelle à cinq autres malades au cours des suites opératoires. Une comparaison des résultats de cette étude avec ceux d'une étude antérieure faite chez des malades sans maladie pulmonaire connue n'a montré aucune différence dans les changements postopératoires des gaz du sang artériel et dans la durée du séjour à l'hôpital.

\section{REFERENCES}

1. Horton, G. E. \& Phillips, S. The expiratory ventilagram, Review of Respiratory Disease. 80: 724 (1959).

2. McKerrow, C. B. The McKesson vitalor. J.A.M.A. 177: 865 (1961),

3. Stein, M.; Koota, G. M.; Simon, M.; \& Frank, H. A. Pulmonary evaluation of surgical patients. J.A.M.A. 181: 765 (1962).

4. Rothfeld, E. L.; Berstein, A.; Weiss, G.; Klausner, M.; \& Crews, A. H. Pulmonary function testing in geriatric surgical patients. Diseases of the Chest. 47: 20 (1965).

5. Seldinger, S. I. Catheter replacement of needle in percutaneous arteriography: a new technique. Acta. Radiol. 39: 368 (1953).

6. Bournos, A. R. Effects of nitrous oxide-curare, ether and cyclopropane on post-operative respiratory adequacy. Anesthesiology. 26: 743 (1965).

7. SpeER, D. L. Adaptation of ventimeter. Anesthesiology. 22: 123 (1961).

8. Johnstone, M. Emphysema and controlled respiration. Anaesthesia. 11: 165 (1956).

9. Siebecker, K. L. \& Curtis, J. K. Anesthesia for patients with pulmonary emphysema: use of positive-negative pressure respirator during pulmonary surgery. Anesthesiology. 18: 856 (1957).

10. Nunn, J. F. The anaesthetist and the emphysematous patient. Brit. J. Anaes. 30: 134 (1958).

11. Converse, J. G. \& Smotrilla, M. M. Anesthesia and the asthmatic. Anesth. and Analg. 40: 336 (1961).

12. Shnider, S. M. \& Papper, E. M. Anesthesia for the asthmatic patient. Anaesthesiology. 22: 886 (1961).

13. Utting, J. E.; Gray, T. C.; \& Rees, G. J. Anaesthesia for the respiratory cripple. Acta. Anaesth. Scandinav. 9: 29 (1965).

14. Stein, M \& Cassara, E. L. Preoperative pulmonary evaluation and therapy for surgery patients. J.A.M.A. 211: 787 (1970).

15. Pratt, P. C. \& Krugh, G. A. Chronic expiratory air-flow obstruction - cause or effect of centrilobular emphysema? Diseases of the Chest. 52: 343 (1967). 